\title{
A Game-Based Approach to Exploring Gender Differences in Smallholder Decisions to Change Farming Practices: White Rice Production in Laos
}

\author{
Silva Larson ${ }^{1, *(\mathbb{C}}$, Anne (Giger)-Dray ${ }^{2,3, *(\mathbb{0})}$, Tina Cornioley ${ }^{2,3}$, Manithaythip Thephavanh ${ }^{4,5}$, \\ Phomma Thammavong ${ }^{6}$, Sisavan Vorlasan ${ }^{7}$, John G. Connell ${ }^{8}$, Magnus Moglia ${ }^{9}{ }^{\circledR}$, \\ Peter Case ${ }^{8,10}\left(\mathbb{D}, K_{\text {Kim S. Alexander }}^{8}\right.$ and Pascal Perez ${ }^{11(D)}$ \\ 1 School of Science and Engineering, University of Sunshine Coast, Sippy Downs, QLD 4556, Australia \\ 2 Forest Management and Development Group (ForDev), Institute of Terrestrial Ecosystems, ETH Zürich, \\ CH-8092 Zurich, Switzerland; t.cornioley@gmail.com \\ 3 Institute of Terrestrial Ecosystems (ITES), ETH Zürich, CH-8092 Zurich, Switzerland \\ 4 School of Agriculture, Food and Wine, University of Adelaide, Adelaide, SA 5064, Australia; \\ thephavanh.mntt@gmail.com \\ 5 National Agriculture and Forestry Research Institute (NAFRI), Nongviengkham Village, Xaythany District, \\ Vientiane Capital P.O. Box 7170, Laos \\ 6 Faculty of Agriculture, National University of Laos, Nabong Campus, Pakxap-Mai Village, \\ Xaythany District, Vientiane Capital P.O. Box 7322, Laos; phommath@gmail.com \\ 7 Provincial Agriculture and Forestry Office, Thameung Village 13000, Kaysone Phomvihane District, \\ Savannakhet Province, Laos; tee.vorlasan@yahoo.com \\ 8 College of Business, Law and Governance, James Cook University, Douglas, QLD 4811, Australia; \\ john.connell@jcu.edu.au (J.G.C.); peter.case@jcu.edu.au (P.C.); kim.alexander56@gmail.com (K.S.A.) \\ 9 Center for Urban Transitions, Faculty of Arts, Social Sciences and Humanities, Swinburne University of \\ Technology, Hawthorn, VIC 3122, Australia; mmoglia@swin.edu.au \\ 10 Bristol Business School, University of the West of England (UWE), Bristol BS16 1QY, UK \\ 11 SMART Infrastructure Facility, Faculty of Engineering and Information Sciences, University of Wollongong, \\ Northfields Av, Wollongong, NSW 2522, Australia; pascal@uow.edu.au \\ * Correspondence: silva.larson@gmail.com (S.L.); anne.dray@usys.ethz.ch (A.D.)
}

Received: 7 July 2020; Accepted: 8 August 2020; Published: 14 August 2020

check for updates

\begin{abstract}
What influences farmers' decisions to adopt agricultural technologies is an important question for international agricultural research projects. There are often interpersonal differences between women and men that influence the adoption of decisions and behaviours, but few studies in the literature focus on these factors. We describe a game-based approach to explore decision-making processes underpinning the adoption of new farming technologies and practices in Lao People's Democratic Republic. Sowing a different rice variety is the tailored technology. The game explored adoption behaviours influencing decisions on transitioning from growing glutinous rice, a traditional variety preferred for consumption, to "white" rice for commercial export to international markets. We conducted separate game-workshops with 36 women and 36 men in 4 villages of southern Laos that were transitioning from subsistence to commercial smallholder production. The gaming exposed various possible behaviours and decisions that women and men considered. Access to resources, both assets and information, was equal for all players, yet women were found to adopt new rice varieties more readily than men and to engage in cooperative behaviours in the game situation. The study highlighted the need for further gender-sensitive research into cooperation among women in the agricultural context-an understanding beneficial for countries and regions undergoing agricultural transition.
\end{abstract}


Keywords: gender; rural development; role-playing game; Laos; adoption; agrarian transition: Companion Modelling

\section{Introduction}

What influences farmers' decisions to adopt introduced agricultural technologies is a central question for international agricultural research projects. Smallholder farmers in Lao People's Democratic Republic (Lao PDR), like many others in developing countries, are facing transformative changes in their traditional agriculture-based livelihoods. With approximately $62 \%$ of labour contributing to the agriculture sector, Lao PDR is still highly dependent on agriculture [1]. However, processes of intensification of agriculture, market integration, industrialization and urbanization are underway [2-6].

Smallholder family farming, understood as a household which combines family, farm and commercial activity, still represents the backbone of the world's agriculture [7]. Traditionally, subsistence farming was predominant in Laos, with smallholders dependent on cultivatable land for rice and livestock husbandry, whilst other nontimber forest and river products are used as supplementary food sources and marketable goods [8-10]. Some $72 \%$ of the total cultivated land area is dedicated to rice production with the traditional glutinous ("sticky") rice varieties, preferred for local consumption and providing almost $70 \%$ of calorie and protein intake [11]. To improve rural livelihoods, however, the Lao government is encouraging farmers to move to commercial agricultural production, with plans to increase both rice yield per hectare and production of nonglutinous ("white") rice varieties; those demanded by major export markets, e.g., China. The key decision for farmers is whether to continue traditional production of the "sticky" rice and ensure family sustenance or adopt the production of "white" rice for the market; the latter option potentially bringing substantial financial benefits. The flip side of the switch to white rice is the threat it carries to preferred subsistence food for the family. Decisions on household agricultural practices are being made in the larger context of industrialization and urbanization, with nontraditional off-farm and nonfarming activities becoming integral to the way that households generate income [12-15].

Women are a vital part of the agriculture sector in Lao PDR, contributing to every aspect of agricultural production [16]. Similar to other emerging economies in Southeast Asia [17] and elsewhere [18-21], the division of labour in smallholder households is gendered, and men and women tend to have different roles and responsibilities. In the rural agricultural context of Lao PDR, data are available that describe the differences between male- and female-headed households, but little is known about the role and contribution of rural women within male-headed households or the decision-making process in such households [22]. Rapid and uneven economic growth occurring in Southeast Asian countries over recent decades has resulted in new and challenging inequities between social groups and between men and women [23]. There are many examples of young men and women migrating for wages and remittances [24-26], with young migrant women becoming the industrial working class of Southeast Asian cities [23].

Understanding specific farmers' behaviours that would prevent or facilitate the adoption of introduced agricultural technologies is important, particularly in terms of understanding possible future farm management scenarios. Ambitious targets for increasing agricultural production and international exports set by the Lao government are based on the premise that agricultural productivity can be boosted by changed farming practices. Modification of farming practices through the adoption of technologies often occurs at a much slower rate than hoped [27-32]. The current low adoption rates of new technologies [33], including white rice production, suggest that more needs to be understood about how farmers decide on their production goals and how the offered technologies might fit with such goals [12]. Recognizing the central role of gender in the process of agrarian and also a wider societal transition in Lao PDR, we argue for the need to explore the differences in behaviours between rural women and men. 
The adoption of new practices results from a complex decision process involving empirical knowledge and individual beliefs, perceptions and interests, combined with personal or collective assets in relation to the institutional context. Nonetheless, understanding decision-making processes, and the necessary intermediate step of eliciting mental models, is a challenging task. Game-based approaches have become a popular means in the field of social-ecological research to study decision-making processes [34,35] and to understand the heterogeneity of mental model constructs [36]. Garcia et al. [35] argue that role-playing games can help to elicit mental models and illustrate decision-making through concrete representations of the needs, constraints and aspirations of stakeholders. Games allow participants to grasp information more easily [37], empower local communities, elicit local knowledge and decision-making processes [38-40] and illuminate complex socio-ecological systems [41,42]. In addition, games allow researchers to better understand how people devise strategic decisions when confronted with complex, sometimes conflicting and uncertain situations. Sensitive issues, such as illegal activities or corruption, that would rarely be communicated in traditional interviews, can emerge implicitly and explicitly during a game session [36,43].

Games also serve as models of strategic situations, allowing participants to anticipate the consequences of actions or decisions [35]. By posing challenges and confronting players with complex situations, games can act as a reality check, whereby participants revisit their pre-existing assumptions, preconceived perceptions, values and knowledge regarding how the "system" works currently as well as how it should work or might work in the future $[38,39]$. Games, when carefully facilitated, operate as "safe spaces" where participants can voice their motivations behind the plurality of their livelihood strategies, and the drivers and thought-processes that influence how they react or adapt to changes, without fear of direct consequences or repercussions in the real world [44,45].

Role-playing games have been used in the past to explore agrarian transition and facilitate understanding of farmers' decision making [46-49]. However, this approach has been underutilized to study the impact of gender in agriculture and landscapes changes [50]. Research techniques commonly used for gender analyses include focus groups, wealth ranking and semistructured or structured interviews [51]. Villamor et al. [52] have expanded the methodological repertoire and broken new ground by using role-playing games to analyse gender differences in forestry research. In this paper, we transpose a similar game-based approach to analyse the influence of gender on the adoption of new technologies and farming practices. We report on our investigation of adoption behaviours as complex decision-making processes, using a participatory role-playing game following the Companion Modelling approach [53]. Central to this approach is the coconstruction of the models or games with local experts and stakeholders through an iterative process.

In this paper, we aimed to understand and compare the decision-making process and behavioural choices of men and women in a context of agricultural innovations. To do so, we explored the different adoption behaviours when men and women are confronted with several new farming practices and technologies. The specific technological intervention we used to explore adoption behaviours is the transition from growing glutinous ("sticky") rice for home-consumption to growing "white" rice (Hom Savanh variety) for sale to international markets. To explore the viability, possible implications and likelihood of this transition, we developed and undertook tailored game workshops to elicit specific behaviours that prevent or facilitate adoption by smallholder farmers of "white" rice for export to China. Gender-specific workshops were conducted with 72 smallholder farmers (36 females and 36 males) in four villages of southern Laos. The gaming workshop allowed participants to examine possible consequences of selecting a new technology (white rice variety) in a no-risk, virtual manner [54]. We specifically explored: (1) potential differences in incomes achieved; (2) technical production choice (patterns of adoption); (3) the role cooperation plays in reaching targets or maximizing outcomes.

In the next section, we introduce the context of rice production in Laos, the participants' profiles, the game elements and the statistical methods employed to analyse the data. We then present the results across three indicators (income, production choices and cooperation) by comparing the male 
and female game sessions. Finally, we discuss the implications for gender-sensitive studies of adoption of new farming practices and the role women play in regions undergoing agricultural transition.

\section{Materials and Methods}

\subsection{Study Context and Game Participants}

This study was part of a wider research project [55] in which qualitative and quantitative data were collected to better understand the issues implicated in the adoption of new technologies in two provinces of southern Laos: Savannakhet and Champasak. The southern provinces are crucial to the Lao PDR government's agricultural strategy and planning as they are the site of seven large plains that have been designated as "suitable for intensive crop production". The research study undertaken in these provinces involved over 950 participants, including 900 farmers and 50 stakeholders involved in data collection exercises [12,14,56-58].

Livelihoods of farmers in selected villages participating in the study were based on rice production and livestock as sources of sustenance and income, with additional income from off-farm work. Using a Bayesian network analysis, Moglia et al. [14] found that the key opportunities important for improving rice farming practices and increasing "white" rice production in this area were:

(1) The use of direct seeding machines that allow farmers to significantly reduce the time required to plant their fields, and hence opens up options for alternative uses of labour. There were several technical concerns about the suitability of direct seeding approaches in terms of its applicability in some geographical areas and resultant weed intrusion.

(2) Access to the market and cooperative agreements between traders and farmer groups, to meet order requirements.

(3) The proper application of fertilizer necessary to increase yields. The soils in the area are generally of poor quality and fertilizer is often inadequately applied.

The above-mentioned factors served as a basis to create the game elements, as described in the next section. In addition to data collected in the wider project, secondary data [59-63] were used to create the context of the game. Realistic game scenarios were constructed in consultation with a range of experts and in reference to the literature.

A total of eight game workshops were undertaken in four villages-Thouat, Phonthong, Alan Wattana and Nonokkhien-located in Savannakhet Province. Overall, 72 smallholder farmers (36 men and 36 women) participated. Provincial and district agricultural extension officers made all local arrangements, particularly appointments with the village head and stakeholder contacts. In each village, two game sessions took place, one with male participants in the morning and the other with female participants in the afternoon. Each game session lasted $3 \mathrm{~h}$ on average. The selection of the participants was facilitated by the Lao Ministry of Agricultural and Forestry officers and the national research team. Most female participants were aged between 41-60 years with the second-highest participant rate in the 25-40 years age group. Male participants were mostly aged $41-60$ years and 25-40 years, but more men over 60 years participated than in the women's groups. Overwhelmingly, men identified themselves as the head of the family with only a few sons, a son-in-law and a grandfather involved. Women mainly identified as the housewife, but $20 \%$ of women identified as the head of the family.

\subsection{Game Development}

A game in the form of "table top" role-playing was developed to mimic an archetypal village in the rice belt of Laos. The purpose of the study was to better understand the gender-specific interactions between farmers, extension officers and traders when being introduced to new technologies and farming practices. The game was designed to confirm key issues identified during research activities that seem to prevent many farmers from adopting new technologies proposed by extension services. 
During the workshop (Figure 1), the participants, in teams of 2 players, made decisions to manage a virtual farm in the face of future seasonal scenarios, with access to a suite of rice crops and farm production options. Players were provided with information about the cost of each option and expected returns or benefits. The objective of the game was to demonstrate conditions under which new technologies could be adopted by a large number of farmers and how farmers, traders and extension officers could work together to ensure the uptake of new technologies.

The games were centred on switching traditional "sticky rice" production to "white rice" for commercial sale. Players were also presented with the option of growing an "improved sticky rice" variety to create a portfolio of choices and options (and move away from a purely binary system of sticky rice versus white rice). As the game unfolded, players could also access a set of accompanying appropriate technologies such as farm machinery (direct seeding machine) and fertilizers.

During the game, details were provided about the new technologies, weather forecasts and changing prices of commodities. At the end of each decision-making period, and again, at the end of each game year, players reviewed and discussed the consequences of their decisions on farm profitability and improvement (or not) to their livelihoods. All game sessions were directly followed by a debriefing phase when players were given the opportunity to reflect on the gaming experience [45]. The debriefing was typically structured around the following questions: "how do you feel?", "what happened during the game?", "why did it happen?", "what would you do differently?", "how is the game reflecting (or not) your reality?" Game sessions were run by trained facilitators and presented in Lao language.

Hereafter, we detail the players' profiles and their objectives, the gamescape (i.e., the landscape of the game board) and the sequence of actions taken by players.

\subsubsection{Player's Profiles and Objectives}

The game included three different players' profiles: farmers, agricultural extension services and traders. The game was tailored to be played by 7 teams as follows:

- Five teams of farmers (with 2 participants per team when available): players were practicing male and female farmers from the participating villages. They all had experience with growing sticky rice, and white rice was grown in the villages by some but not all of them. The objective of each farmer's team was to feed her/his family and pay "taxes" to cover school, health and electricity expenses. To be able to do so, farmers had to produce rice (either sticky, improved variety or white rice) and earn money tokens. They could also sell their livestock or send their labour forces (i.e., labour tokens) to Thailand.

- A team of extensionists: players on this team were the local District Agriculture and Forestry Officers; hence, they were familiar with the participating village's production and socio-cultural systems. They were also familiar with the new technologies being proposed in the game, as these technologies were selected based on their "real life" relevance. The extension officers' team was given "the mission" to convince as many farmers as possible to adopt one (or more) of the following new technologies: (1) switching to "improved sticky rice", (2) use of direct seeding machine and (3) use of high quality fertilizer. To encourage the uptake of new technologies, extension officers could distribute free "technical packages" (such as free fertilizer or use of the direct seeding machines); however, the distribution of "goods" for free per round was limited due to the limited (imaginary) budget of the District Agriculture and Forestry Office. No rules were set on how to distribute these "goods"; it was entirely up to the extension officers to decide on the process.

- A trader: this was the only role in the game that was not played by the "actual" actor. Rather, the role of the trader was scripted and performed by a member of the research team. Her/his job was to sell inputs and new technologies, such as improved sticky rice seeds, white rice seeds, fertilizer, direct seeding machine and cattle and fodder, to the farmer, enabling the farmer to make management and adoption choices. The trader appeared at the beginning of each round when he/she would pay a visit to the village. The trader re-appeared at the end of each turn and could 
purchase the outputs from the farmers (rice, cattle). The trader fixed the prices and expected quantities for the white rice at the start of the game.

\subsubsection{The Gameboard}

The game consisted of five individual gameboards-one for each participating farmer team of two players - that in their entirety embodied a typical village in the area under study and its surrounding farmland during the rainy season. A single board represented one farm and consisted of the following seven zones (from bottom to top, Figure 1b):

1. An irrigated rice paddy field located near the river (lowest area on the board). It had plenty of water, but in years with too much rain, it could be flooded.

2. Another irrigated paddy field, but in years with a low amount of rain, the irrigation system could not provide enough water to this area.

3. A rainfed paddy field, where rice production depended on the quantity of rainfall during the rainy season. The soil was good.

4. Another rainfed paddy field, where rice production depended on the quantity of rainfall during the rainy season. This area had bad soil.

5. Grazing land near the farm.

6. The farmhouse.

7. This is a special area; it represented a factory in Thailand where players could send their family members (in the form of labour pawns) for off-farm income.

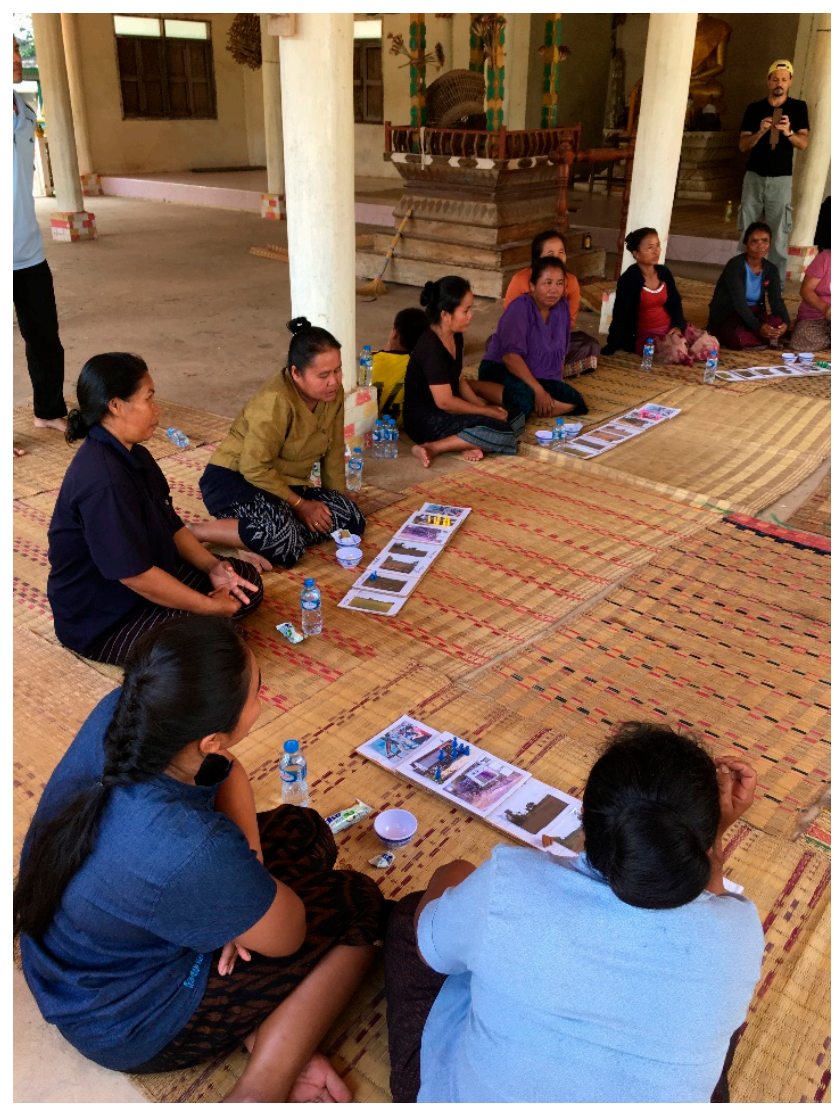

(a)

Figure 1. Cont. 


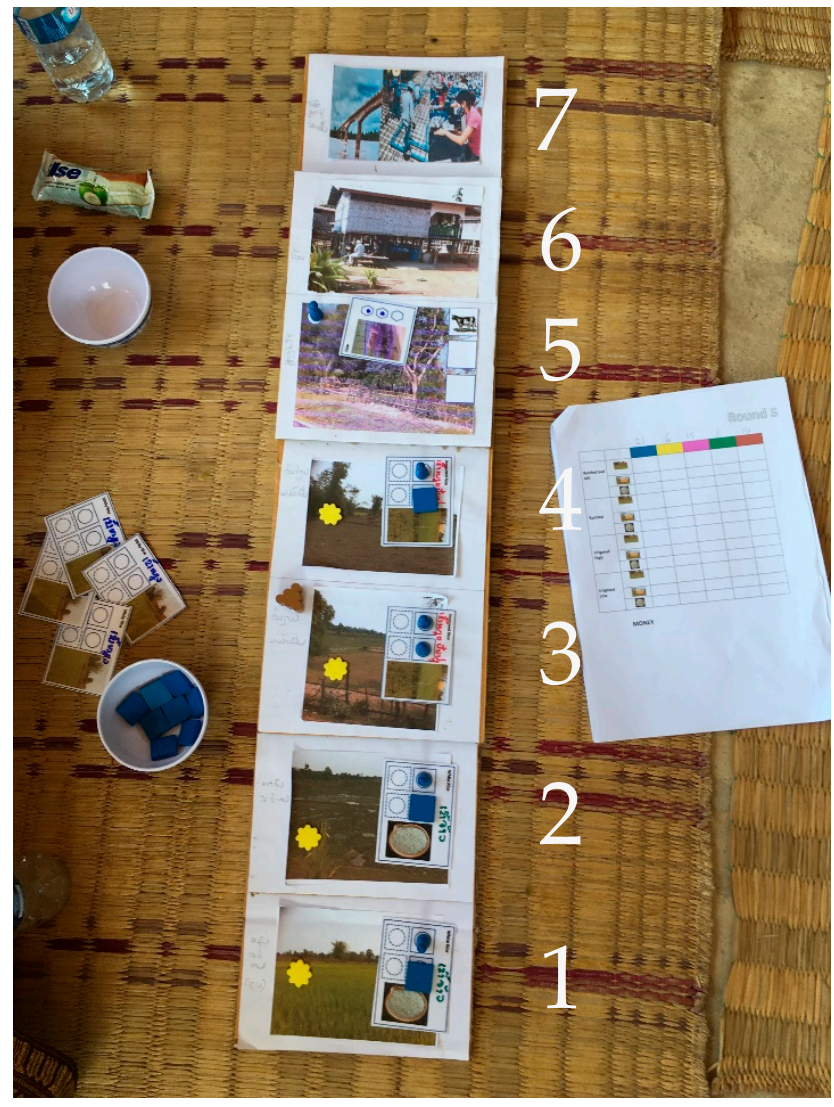

(b)

Figure 1. (a) Alan Wattana session with women paired in teams of 2; (b) single board for "blue" player with the 7 areas (labelled from 1 to 7 ) and recording decisions grid filled by the observer.

\subsubsection{Rounds and Sequence of Events}

Each round of the game represented one year, with only the rainy season being actively played, reflecting an annual single wet season crop from paddy production. Each gaming session consisted of five rounds (corresponding to 5 years). A description of the game elements and the sequences of events can be found in Appendix A. The game rules were as follows:

- Rainfall: The timing of weather events was scripted and was identical across all workshops. The weather conditions were either "good" or "bad", leading to different yields on the rainfed fields. "Good" meant positive yields (corresponding to an average wet season), and "bad" meant reduced yields (corresponding to a year with little rain). Additionally, floods could occur, influencing the lower irrigated rice paddy. Rounds 1,3 and 5 were good rainy years, round 2 was a year with little rain, while flooding occurred in round 4.

- Players' tokens and actions: Farmers started with two types of tokens: labour pawns and money. Each farmer received eight labour pawns, with one pawn representing approximately 10 days work and eight money tokens of 500,000 Lao Kip each ( USD 55). Players could allocate labour entirely to one activity or a combination of: (1) rice cultivation on one of the four fields; (2) cattle herding; (3) off-farm work in Thailand; or (4) staying at home. 
- Rice cultivation: Players chose between the traditional sticky rice, improved sticky rice and white rice. The game started with traditional sticky rice production only. In year two, improved sticky rice, which produced 1.5 more bags of rice than its traditional counterpart, was also available. White rice for the sale (commercial) production option was introduced into the game from year 3 onwards. Farmers could also choose to use external inputs, including a direct seeding machine (reducing workload) and fertilizers.

- Cattle fattening: Each farmer initially received one cow token. Cattle could have 4 stages of fattening, represented by the fields coloured on the cow-card. The farmers could choose to fatten their cattle. To do so, they could either place the cow token on a grazing area or feed the cow token with fodder bought from the trader. If fattening the cattle, they had to allocate one labour pawn to remain with the cow token. The price received at sale depended on the stage of fattening of the cow token.

- Players' income: Players could generate income by selling rice, cattle or working off-farm. Sticky rice (whether from a traditional or improved seed) was sold for the fixed price of 1 unit of money per bag of rice. White rice was sold for the same price, except when all the players succeeded in cumulatively producing at least 29 bags of white rice. In this case, they could sell white rice for a price premium of 1.5 unit of money per bag of rice.

\subsubsection{Scenarios and the Special Focus on White Rice}

In each round, farmers had to allocate their labour/resources across their land plots and on the Thailand plot in case they opted for off-farm income. As detailed in 2.2 (above), the technical innovations that could occur in the game were based on the previous project findings, literature and consultations with the stakeholders and included the use of fertilizers, improved rice varieties and direct seeding machine. Technical innovations were introduced by the extension team along with the provision of sample inputs they could give to one of the five farmers' teams of their choice. These were also available for sale by the trader.

From rounds 2 to 4 , a different climatic or economic scenario that would affect outcomes was introduced: drought in round 2 (lower yields on rainfed soils), global financial crisis in round 3 (no off-farm income), flood in round 4 (no yield on lower paddy).

Additionally, from round 3 onwards, the economic scenario of interest was the traders' pressure and opportunity to sell "white rice" to the market. The trader offered the player a premium price if they could collectively produce a minimum of 29 bags of "white rice". This threshold was established during the game calibration and crash-tests. Note that this scenario directly conflicted with the extensionist objective of promoting an improved rice variety for food security.

\subsection{Data Analysis}

Player's decisions were documented throughout the game (Figure 1). Each pair of players' income from sticky rice, white rice, off-farm work and selling cattle, as well as their total income, were recorded at each round. We also recorded at the end of each round: the rice type cultivated on each plot; fertilizer use; the cumulative number of bags of white rice produced; the cumulative number of direct seeding machines owned (DS machine owned); the fraction of those that were shared (DS machine sharing). Placement of these resources and the outcome of each season were carefully documented using a decision grid (Figure 1). The grid provided a numerical dataset that was used to analyse behavioural patterns. 
We fitted six linear mixed-effects (lme) models to explore potential differences in strategies and outcomes between men and women over 5 rounds to account for the random effects of the village and player ID (i.e., the team colour). One model was fitted for each response variable of interest, namely total income, white rice income, sticky rice income, production of white rice, DS machine owned and DS machine sharing. The analyses were performed in R [64] with the lme4 package [65]. When the response variable was measured per round, per village and per player, we accounted for the random effects of the village and player ID nested within the village. When the response variable was measured per round, per village and not per player, then we accounted for only one random effect: village. To explore differences in income, we considered the fixed effects of the round of the game (rounds 1-5), gender and their interaction. For the models "white rice income" and "sticky rice income", we further accommodated a quadratic effect of the round of the game and its interaction with gender.

For the models "white rice production", "DS machine owned" and "DS machine sharing", we accounted for a fixed effect for round and gender but not their interaction, as including the interaction led to model overfitting. We fitted a lme model with a Poisson distribution for "DS machine owned" and binomial logistic regression for "DS machine sharing". For the other lme models, we used a Gaussian distribution. We additionally fitted two fixed-effect-only binomial logistic regressions instead of mixed effect models, as the same models with random effects did not converge [66].

To investigate potential differences between men and women in white rice cultivation, we fitted a model on white rice cultivation explained by gender, round, plot properties and all possible two-way and three-way interactions. We further fitted a regression on fertilizer use to assess the probability of using fertilizer on a plot depending on gender, round, plot properties and rice type. Interactions were not considered because of overfitting.

\section{Results}

We reported on the following variables of interest from the "table top" role-playing game: income, production choices (adoption in terms of technical decision-making patterns-plot selection and use of fertilizer) and the role cooperation plays in maximizing outcomes. A number of other game elements, as presented in Appendix A, is not reported here, as no differences between male and female reactions were noted. We do, however, encourage further explorations of such themes. Statistics of the results presented here, and additional figures can be found in Appendix B.

\subsection{Income}

The income of both men and women increased over time and women achieved a higher income than men as the game progressed (Figure 2: intercept $(\mathrm{men})=3.760$, se $=1.366$, intercept (women vs. men) $=-0.821$, se $=1.520$, slope $($ round $)=2.700$, se $=0.323$, slope (round women vs men) $=0.906$, se $=0.460$ ). Figure 2 shows the output of the mixed-effect linear model with a Poisson distribution including Gender and Round as fixed effects, and village and players nested within the village as random effects. 


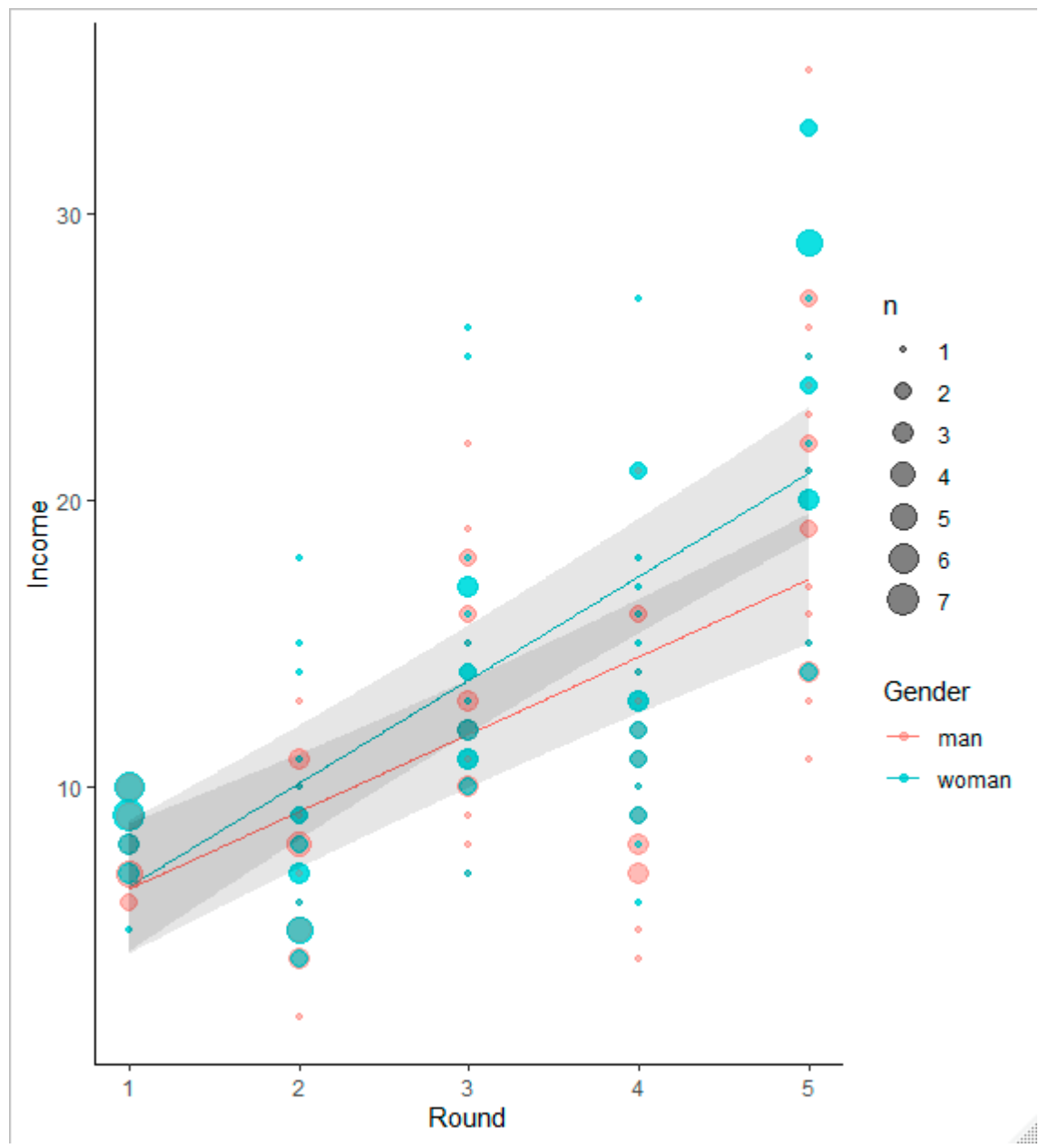

Figure 2. Income per player over rounds for men (20 teams) and women (20 teams). The dots represent not one observation but a group of observations sharing the same values. The size of the dot is proportional to the number of observations (n) with the same $x$ and $y$ values. Some of the dots for males are behind the dots for females (see transparency). The lines are predictions from a linear mixed effect model while the grey ribbons represent the corresponding $95 \%$ confidence intervals from the fixed effects.

Exploring the income outcomes more closely, we checked the money units generated from four sources of income (Figure 3): white rice (mean $=5.04$ money units, sd $=5.84$ ); sticky rice (mean $=4.80$ money units, $\mathrm{sd}=3.20)$; selling cattle (mean $=2.00$ money units, $\mathrm{sd}=2.73$ ); off-farm workers (mean $=0.87$ money units, $\mathrm{sd}=1.09)$. We observed that before white rice was introduced in round 3, traditional "sticky" rice (Figure 3c) was the main source of income for both men and women. White rice was introduced in round 3, and from then on, the majority of players' income stemmed from white rice (Figure 3d). The income generated by selling cattle (Figure 3a) and from off-farm workers (Figure 3b) was marginal compared to income from selling white rice. Therefore, we only further investigated the trends in income from sticky rice (traditional and improved) and white rice. 

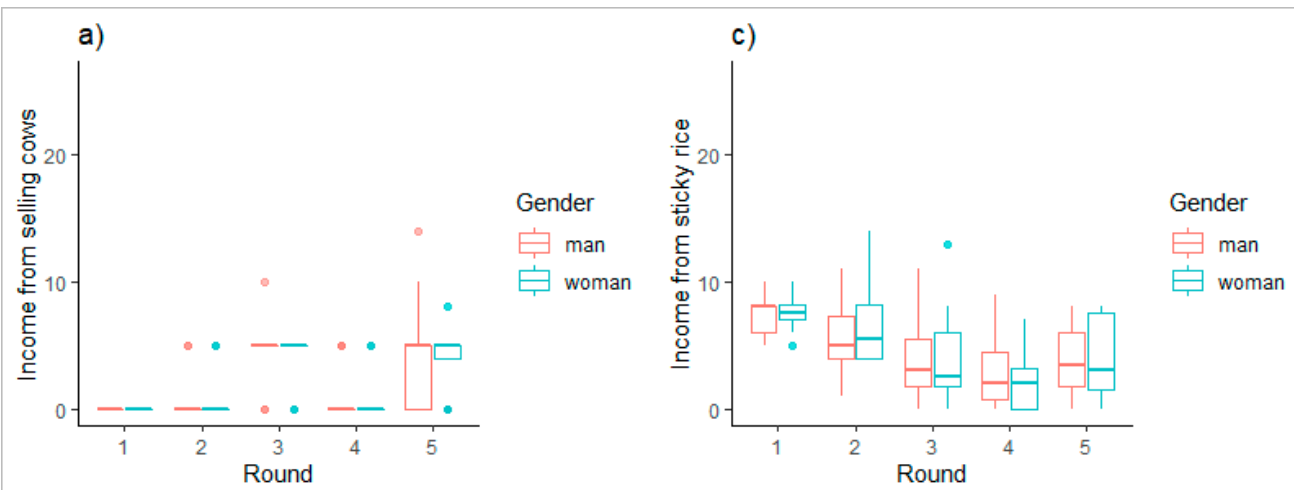

b)

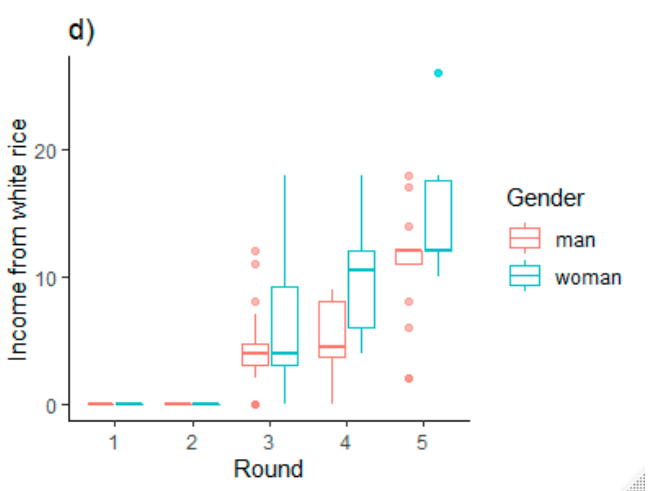

Figure 3. Boxplots of the observed income of players generated by four different sources of income, per round and gender, all villages cofounded, (a) from selling cattle, (b) from off-farm workers, (c) from sticky rice, whether standard or improved, (d) from white rice. The income from off-farm workers was zero in round 3, because in this round, workers sent off-farm failed to secure employment. The income generated from selling cattle in round 1 and the income from white rice in rounds 1 and 2, was zero because those options were not yet available to players.

There was no discernible difference in the increasing trend of income generated by sticky rice over time between men and women (Figure 3c). Women achieved a higher income from white rice than did men once white rice became available in the rounds (Figure $3 \mathrm{~d}$ ).

\subsection{Production Choices}

White rice production at the player level was determined not only by the amount of white rice cultivated but also by management decisions, including plot choice and use of fertilizers.

Women and men were equally likely to allocate most of their plots to white rice once it was available, from round 3 onward. The important distinction in terms of income, however, was that women were more likely to allocate their best plot—-the paddy protected from flooding and with a high yield (paddy highland, PH, in Figure 4-to white rice. This was not because men were less interested in maximising income, but because, as male players in village Alan Wattana explained during debriefing, "We need to plant more sticky rice because our family is eating sticky rice, and so we can't produce enough white rice for trader". 


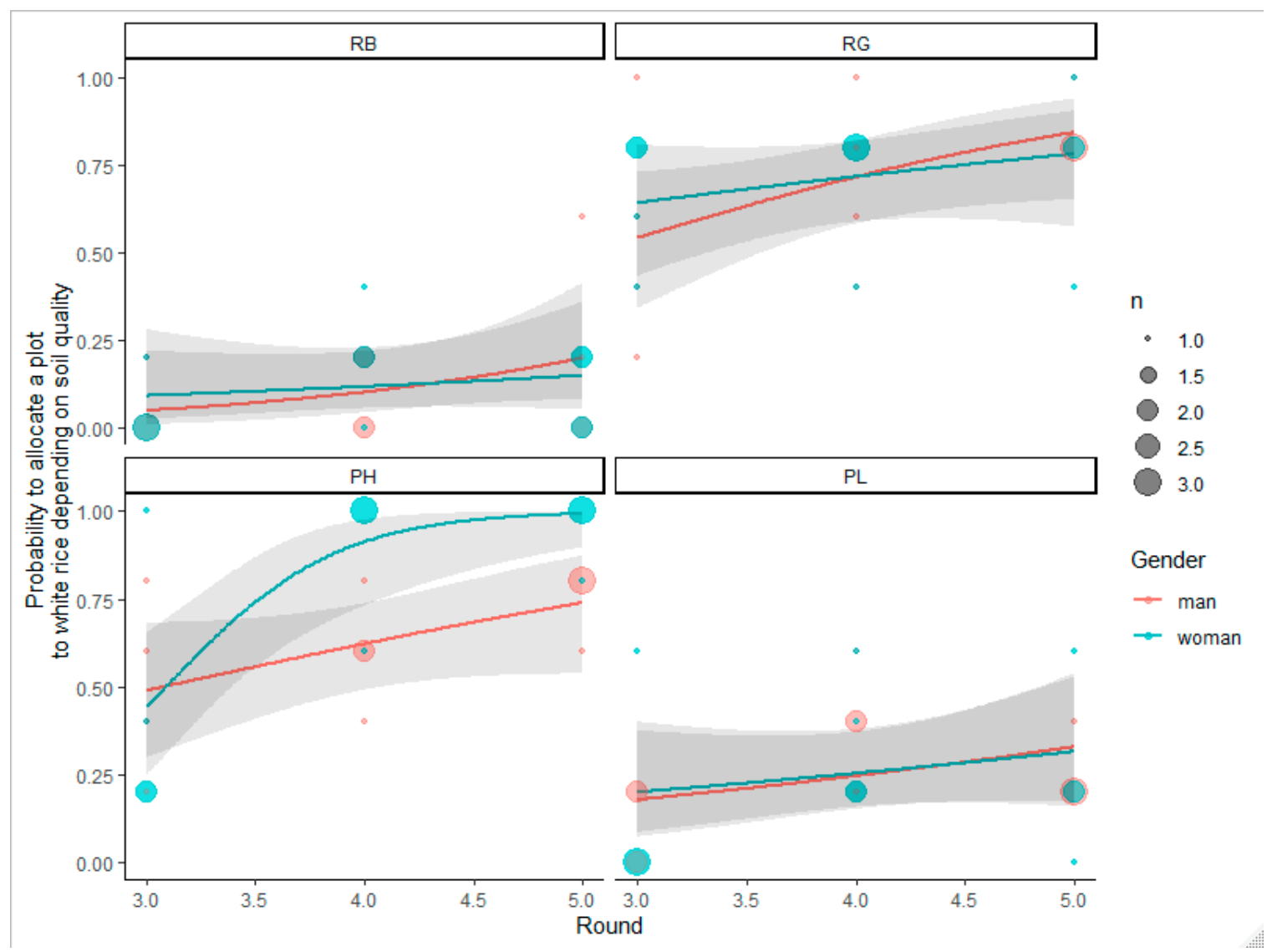

Figure 4. The probability of allocating a plot to white rice cultivation depending on plot properties: rainfed with bad soil (RB), rainfed with good soil (RG), paddy highland (PH), paddy lowland (PL). Each circle represents the observed fraction of the plot of a given plot property allocated to white rice cultivation per game session. The size of the circle is proportional to the number of observations of the same values. The lines are predictions from a logistic regression, while the grey ribbons represent the corresponding $95 \%$ confidence intervals.

Fertilizers were increasingly applied over time, with no noticeable difference between men and women (Appendix B). Players were more likely to apply fertilizers to white rice compared to sticky rice, while no significant difference was detected between improved sticky rice and white rice. From the game components (Appendix A), production increases the most by applying fertilizer to improved rice compared to either white rice or sticky rice. Fertilizer on improved sticky rice increased production by 1.5 bags of rice (average during a good year over the four plot types), while it increased production by only 1 bag of rice when applied to areas of white rice or sticky rice production. However, in optimum conditions, white rice could be sold for 1.5 units of money per bag compared to only 1 unit of money per bag for sticky rice. Thus, applying fertilizer on a plot of improved rice or white rice was equally profitable.

\subsection{Cooperation}

More white rice was produced at the village level when women were playing, and in those sessions, the threshold of 29 bags of rice was reached earlier (Figure 5) to obtain the premium price. Women produced more white rice and hence achieved higher profits sooner than did men when playing the game. 


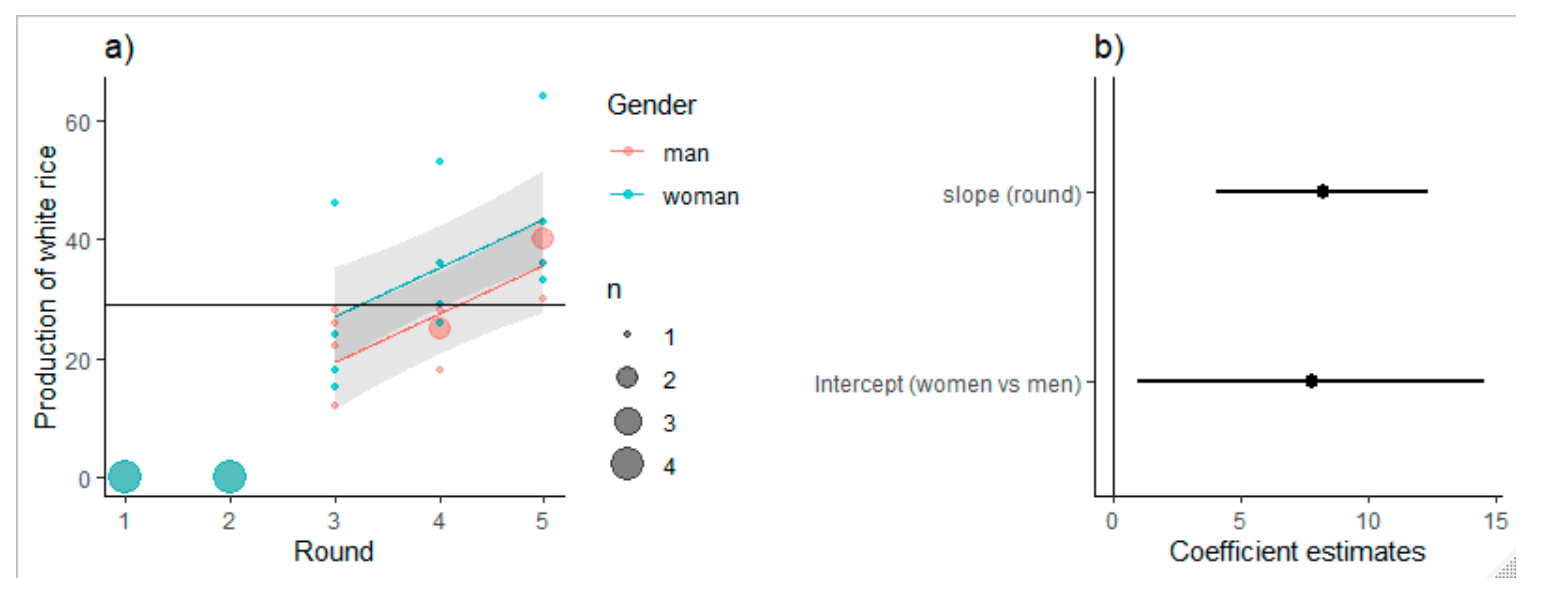

Figure 5. Trends and corresponding coefficients of white rice production at the session-level by round. (a) The production over the rounds for men in pink and women in blue. The dots represent observed data, and the size of the dot is proportional to the number of observations of the same values. The black horizontal line is drawn at 29 , the threshold above which players receive a price premium for white rice. The straight lines in colour are predictions from a linear-mixed effect model, while the grey ribbons represent the corresponding $95 \%$ confidence intervals from the fixed effects. (b) The regression coefficient estimates (dots) with their corresponding 95\% confidence intervals (whiskers) of the fixed effects of the model used for prediction in (a). Coefficient estimates whose confidence intervals exclude zero can reasonably be considered to affect the response variable.

In addition to cooperating to achieve the target of 29 bags of white rice to obtain the price premium, cooperation was also important in terms of needing to share the use of the available direct seeding machine. Although men and women were equally likely to own a direct seeding machine, women were more likely to share the available machines with other farmers. In addition, when machines were shared, players-even those unable to afford the cost of 6 money units to purchase-were able to use the machine and hence halve the number of labour tokens required to farm a plot. The labour tokens that became available could then be used to perform different actions to further increase farmers' income.

\section{Discussion}

In the game, the income of both men and women increased over time, but women achieved a higher income than men as the game progressed. Women achieved a higher income due to their higher levels of collaboration, tending more quickly to achieve the production of 29 bags of white rice required for a premium price. Women's higher propensity to collaborate and cooperate is recorded in the literature, specifically when they are in a female-only environment [67,68], and this has also been noted in other experimental game settings [69,70]. Some studies, however, suggest that, overall, women and men can be equally cooperative, with sex differences in cooperation entirely context-dependent [71,72], whereas other research suggests that the effect of gender on cooperation remains inconclusive [73]. Nonetheless, it needs to be noted that most of the literature reported are on social dilemma studies that are conceptually concerned with situations involving a conflict between self-interest and the collective interest [71]. Gendered exploration of cooperation in a specific context of agriculture with the potential neutral-win and win-win outcomes, warrants further study as it potentially carries more relevant policy implications than can be generated exclusively through social dilemma studies.

While there was no difference between men and women in terms of fertilizer use, an important management decision-making difference was that women were more likely to allocate their best plot to white rice. Men were more reluctant to do so as they placed higher value on rice for subsistence. This supports findings from other studies that indicate that subsistence farming is the preferred livelihood strategy for fewer than $20 \%$ of men and $10 \%$ of women [74]. This finding indicates that not only is a transition to a modern agricultural economy well on its way in Lao PDR, but women 
also appear more willing to exit the traditional farming context. Moglia et al. [74] also reported that almost two-thirds of women in their study opted for maximizing family income through off-farm employment, compared to nearly two-thirds of men who focused on either growing rice for subsistence or income-generation. In this study, we also found indications of income-maximization strategies: in addition to cooperating to reach the target number of rice bags and hence premium price, women were also cooperating by sharing machinery. These actions released additional labour to engage in alternative on-farm and off-farm income-generating activities. This finding is very much in line with other studies that show that nontraditional off-farm and nonfarming activities have become integral to the way households generate income in Lao PDR [12-15], as well as in other emerging economies [75].

Our findings that women changed farming practices earlier in the game than men might appear contrary to some literature claiming that women are slower innovation adopters. Similar to our study - and contrary to expectations and gender stereotypes-Villamor et al. [52] found that females were more active and dynamic than men in responding to external opportunities. Using role-playing games (RPGs) in a female-only and male-only group setting, they found that women who played the RPGs approached land-use change in a more dynamic way than men from the same villages, reacting more positively to external investors and possible changes. The game context of our study might have affected certain outcomes. Unlike in reality, women had access to production inputs and information about new practices equally to men. This, however, is not always the case in the "real" world, and an increasing number of studies acknowledge that it is access to inputs and information, not their behavioural propensity, that prevents women from the adoption of new and improved agricultural practices [76,77]. Peterman et al. [78] also found that across different types of inputs, men generally have higher input measures than women and that this input gap was responsible for productivity differences between men and women observed in their study. On the whole, these results from various studies suggest that technology adoption decisions depend primarily on access to resources, including land, labour and information, rather than on gender per se [78-80]. If in a particular context, men tend to have better access to these resources than women, Doss and Morris [73] argue that the technologies will not benefit men and women equally. Policy changes thus may be needed to increase women's access to key resources rather than necessarily to focus on the motivational factors that might purportedly encourage women to adopt innovations. Of relevance here is also a study by Ogunlana [81], who argued that female farmers easily adopt innovations that enhance their economic status. In other words, a low participation of women in agricultural innovation adoption is caused by lack of information about the advantages of the innovations. Such findings have important policy implications because they suggest that ensuring the more widespread and equitable adoption of improved technologies may not require changes in the research system but rather the introduction of measures that ensure better access for women to complementary inputs, especially land, labour and agricultural extension services. Therefore, in order to predict whether the new technology will be adopted successfully by women as well as men, it is important to examine both the technology itself as well as the physical and institutional contexts in which the technology is implemented [76].

Improved communication of innovation benefits [81] may also be a significant factor. Furthermore, the aspect of gendered power dynamics on the farm, noted in the previous paragraph, is of relevance here. Importantly, enhancing the economic status of the farm is by no means the same as enhancing the economic status of women on the farm. As Doss [82] argues for African women farmers, who are typically reported as less likely than men to adopt improved crop varieties and management systems, studies too often concentrate on how gender affects technology adoption and not on how the introduction of new technologies affect women's well-being. Our results suggest that once women have access to assets and information equally with men and understand the potential economic benefits of proposed actions, they might be faster adopters of improved technologies and practices than men. On the other hand, such a result might be due to differences in the farming experiences, risk aversion and other characteristics of males and females. In the case of Laos, as Moglia et al. [69] report, women have less emotional attachment to existing agricultural lifestyles, which might result in their greater 
propensity for adoption of new technologies. That said, however, if considerable risks are associated with adoption, women are more likely to move away from agriculture altogether [69]. As this finding is of significant policy relevance, we strongly recommend further studies.

The gaming approach methodology that was used was well received by both local experts and farmers. The approach allowed stakeholders to explore complex interplays and elicit specific behaviours. Gaming is a research methodology that combines community engagement and data collection and is particularly useful for exploring the potential consequences of strategic decisions in agriculture [54]. Overall, the game was perceived as engaging and educational. During the debriefing discussions, farmers indicated that, for them, the game tool had an educational effect because it demonstrated the concepts of strategic resource allocation of farming systems and the potential benefits of longer-term planning horizons. It also resulted in a mind shift for local agricultural officers, who started playing the game with the focus on "technology". Over time, however, they started to appreciate and tried to better understand the actual potential users of the technology—farmers-and their needs and motivations.

As reported elsewhere in the literature, gaming afforded farmers the opportunity to conceptualize their livelihood options and gave them insight into decision-making factors. It also engaged local communities and had a capacity-building effect [38-40,83]. Moreover, games provided the farmers with an opportunity for observing the implications of their decisions on their livelihoods. Villamor and Badmos [34] found that the game was instrumental for eliciting the players' subjective perceptions, goals and expectations within the specific context described but were limited in facilitating social learning in terms of changes in values and norms. The gaming in our study was somewhat confronting to research teams and stakeholders present at the gaming sessions (extensionist services/local agricultural services) as it provided instant, strong and visual challenges to deeply rooted assumptions and myths. For stakeholders who played their own roles as extensionists, it generated new insights by enabling them to explore the potential and gendered consequences of strategic decisions in agriculture. We suggest, in line with Ogunlana [81], that promoters of new technologies, whether governments or donor organizations, need to better understand the economic advantages of the proposed innovations in the specific context. Our findings indicate that communication of economic advantages of innovation, and not the mere availability and access to innovations per se, is of policy importance in terms of encouraging greater levels of adoption by women. We advocate that game-based approaches can be considered when trialling new technologies/practices in the complex context of village and household decision-making. It enables potential beneficiaries to see how scenarios play out and can help counteract risks that are sometimes revealed during initial research activity phases of a project intervention.

To avoid potential shortcomings of the gaming approach, games need to be representative so that the virtual village situations developed by a core team of scientists and targeted stakeholders correspond to the local social-ecological context $[38,39]$. Game authenticity, that is, the level at which it is similar to the actual context of the phenomena under study, is thus an important consideration when developing the game. This, in turn, requires comprehensive preparation, several rounds of crash-testing and fine-tuning and team capacity building. Gaming sessions generate comprehensive sets of data and insights; hence, they require a lengthy interpretation process. In line with Fisher et al. [54], we found the game-workshop capable of enabling the exploration of complex issues within a limited timeframe. The approach enabled the identification of information needs for farmers in a specific region. However, this specificity makes games more difficult to extrapolate to different geographic and temporal settings, as different market conditions, prices, availability of inputs, etc., might change outcomes. It is, therefore, not so much the specific decisions per se, but the decision-making process and behavioural choices, that are the key learning factors of the game approach. Important to the understanding of gendered decision-making, games highlight the decisions that can be made on-farm, even in a highly simplified set-up. 


\section{Conclusions}

Gendered studies of adoption decision-making are limited. We used a game-based approach to explore decision-making processes behind the adoption of white rice farming, in the context of a gradual transition from subsistence to commercial smallholder production supported by Lao government. The approach was found to be well accepted and of benefit to the players. Game-workshops allowed for the elicitation of behaviours and decisions that could be made by women and men in a farm context and in the absence of constraints of time, resources and logistics, based on data from a virtual scenario. Our results suggest that once women have access to assets and information equally with men, and understand the reported economic benefits of proposed actions, they are faster adopters of improved technologies and practices than men. This is a key finding that carries wider policy implications. There is scope for developing the promising findings of this paper, and we recommend further research in the following areas: (a) gendered explorations of cooperation among women in the agricultural context; (b) exploration of benefits of agriculture and agricultural innovation to women on the farm; (c) impacts of out-migration on availability of farm labour. Such studies, we suggest, would be beneficial and widely applicable in the context of countries and regions undergoing agricultural transition from subsistence to commercial agricultural commodity production.

Author Contributions: Conceptualization, P.P., A.D. and K.S.A.; methodology, A.D., P.P., M.T., P.T. and M.M.; validation, A.D. and P.P.; formal analysis, T.C.; investigation, A.D., P.P., M.M., P.T., M.T., P.S., J.G.C. and S.V.; resources, A.D.; data curation, A.D.; writing-original draft preparation, A.D. and S.L.; writing-review and editing, A.D., M.M., K.S.A., S.L., P.C.; visualization, A.D. and T.C.; supervision, K.S.A.; project administration, K.S.A., P.C.; funding acquisition, K.S.A., P.C. All authors have read and agreed to the published version of the manuscript.

Funding: This research was funded by the Australian Centre for International Agricultural Research (ACIAR) (Project no. ASEM/2014/052: "Smallholder farmer decision-making and technology adoption in southern Lao PDR: opportunities and constraints").

Acknowledgments: We would like to thank staff based in our Lao partner institutions for their support and assistance, namely, colleagues at: the National University of Laos, the National Agriculture and Forestry Institute and the Department of Technical Extension and Agro-Processing. Our thanks go to the workshop participants, the local organizers and our colleagues for their comments and play-testing the games prior to fieldwork.

Conflicts of Interest: The authors declare no conflict of interest.

Data Availability Statement: Data collection was approved by the James Cook University Human Ethics Research Committee, approval number H6109.

\section{Appendix A. Description of the Game Elements}

Sequences of events in the game are presented in Table A1.

Table A1. Sequence of events.

\begin{tabular}{cccccc}
\hline Round & Round 1 & Round 2 & Round 3 & Round 4 & Round 5 \\
\hline Weather & Good & Bad & Good & Good & Good \\
\hline Event & $\begin{array}{c}\text { Election of the } \\
\text { Head of the Village }\end{array}$ & Wedding & Crisis & Flood & \\
\hline Trader can sell: & F & F-C-Fo & $\begin{array}{c}\text { F-C-Fo-DSM } \\
\text { WR-IR }\end{array}$ & $\begin{array}{c}\text { F-C-Fo-DSM } \\
\text { WR-IR }\end{array}$ & $\begin{array}{c}\text { F-C-Fo-DSM } \\
\text { WR-IR }\end{array}$ \\
\hline $\begin{array}{c}\text { Extensionist } \\
\text { gives away: }\end{array}$ & & DSM-IR-F & IR-F & IR-F-IP+C & IR-F-IP \\
\hline
\end{tabular}

F: Fertilizer; C: Cattle; Fo: Fodder; DSM: Direct Seeding Machine; IR: Improved Rice; WR: White Rice; IP: Improved Pasture. 
- Election of the head of the village (Round 1): Each farmer is assigned a colour. The head of the village is elected by putting a token of each colour in a bag. The game master will then randomly draw one. The farmer which was assigned the colour drawn will be elected head of the village.

- Wedding (Round 2): The farmers draw a chance card. The one who draws the card with the couple on it will be getting married. He, therefore, draws a token out of the bag. The farmer of the colour drawn has to give one labour force to the one with the card. The player getting married has to pay for the wedding expenses amounting to two money tokens.

- Bad weather (Round 2): Bad weather occurs and lowers the productivity on the rainfed areas. The yield will be the same on these fields, with or without fertilizer.

- Crisis (Round 3): It is the year of the global financial crisis. The labour tokens sent to Thailand will not bring any money home.

- Flood (Round 4): The lower irrigated rice field is flooded. In consequence, this field's yield amounts to zero.

Yields of 'good' and 'bad' weather years are presented in Tables A2 and A3, respectively.

Table A2. Yield on the "good weather" year.

\begin{tabular}{ccccc}
\hline & \multicolumn{2}{c}{ Sticky/White Rice } & \multicolumn{2}{c}{ Improved Rice } \\
\hline & No Fertilizer & Fertilizer & No Fertilizer & Fertilizer \\
\hline Rainfed-bad soil & 2 & 3 & 3 & 4 \\
Rainfed-good soil & 3 & 4 & 4 & 5 \\
Irrigated-high & 3 & 4 & 4 & 6 \\
Irrigated-low & 3 & 4 & 4 & 6 \\
\hline
\end{tabular}

Table A3. Yields on the "bad weather" year.

\begin{tabular}{ccccc}
\hline & \multicolumn{2}{c}{ Sticky/White Rice } & \multicolumn{2}{c}{ Improved Rice } \\
\hline & No Fertilizer & Fertilizer & No Fertilizer & Fertilizer \\
\hline Rainfed-bad soil & 1 & 1 & 2 & 2 \\
Rainfed-good soil & 2 & 2 & 3 & 3 \\
Irrigated-high & 3 & 4 & 4 & 6 \\
Irrigated-low & 3 & 4 & 4 & 6 \\
\hline
\end{tabular}

\section{Appendix B. Additional Statistical Analysis and Figures}

Fertilizer use, Figure A1: Players increasingly apply fertilizers to their plots over time, with no noticeable difference between men and women. Players were more likely to apply fertilizers to white rice compared to sticky rice, while no significant difference was detected between improved rice and white rice. From the game mechanism, production increases the most by applying fertilizer to improved rice compared to either white rice or sticky rice. Fertilizers on improved rice increase production by $1.5 \mathrm{bag}$ of rice (average during a good year over the four plot types), while it increases production by only 1 bag of rice when applied on white rice or sticky rice. However, in optimum conditions, white rice can be sold for 1.5 units of money per bag compared to only 1 unit of money per bag for sticky rice. Thus, applying fertilizer to a plot of improved rice or white rice is equally profitable.

Players were more likely to apply fertilizer on PH plots compared to PL and RB plots, with no marked differences between PH plots and RG plots. From the game mechanism, during good years (rounds 2, 3-5), adding fertilizer increases the production of rice by 1.33 bags of rice on PH and PL (average over all three types of rice), while it increases production by 1 unit on RG and RB. Given that $\mathrm{PL}$ is occasionally subjected to flooding, production is best increased by placing fertilizers on $\mathrm{PH}$. 

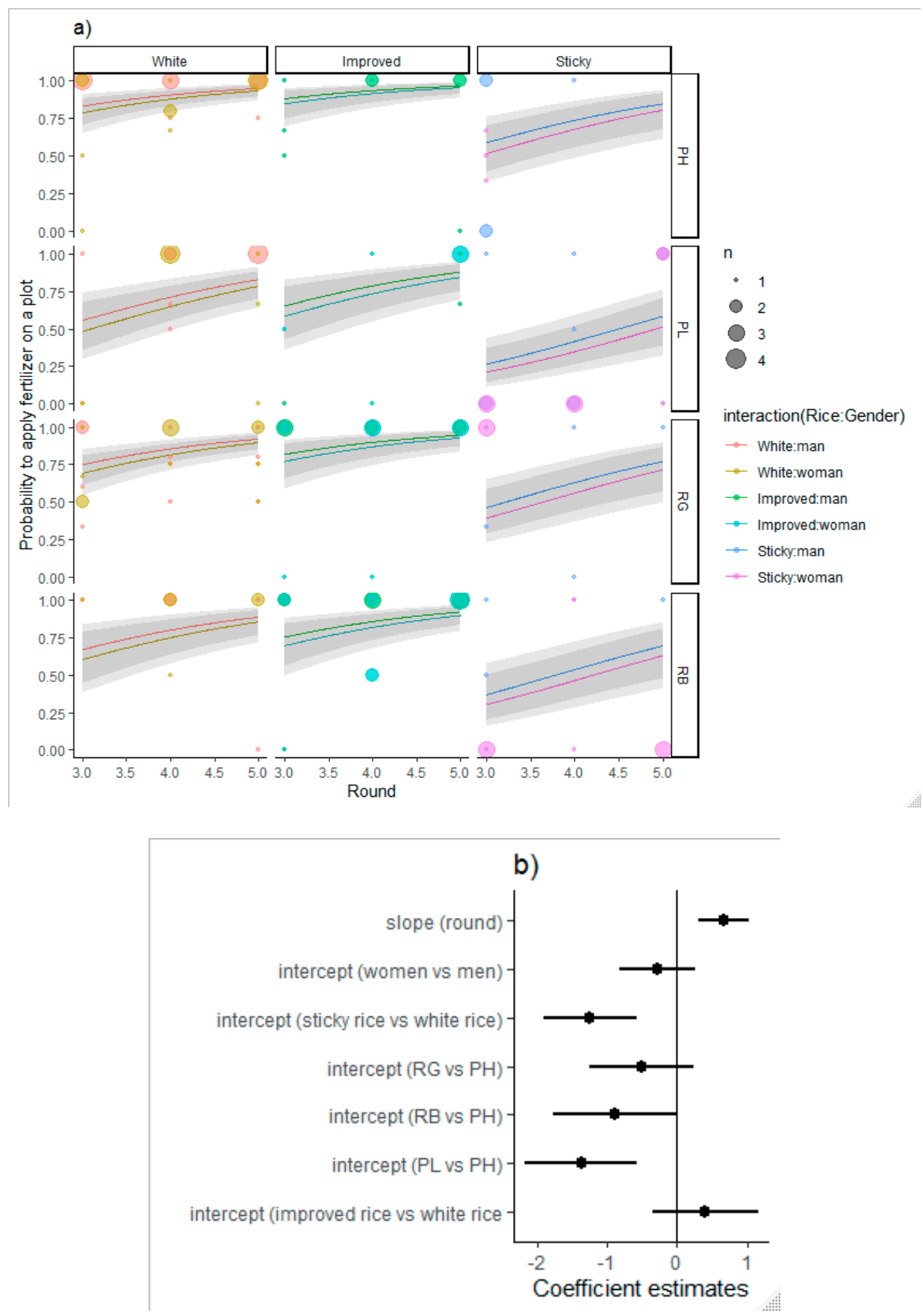

Figure A1. (a) Trends in the probability to apply fertilizers to a given plot property (rainfed with bad soil (RB), rainfed with good soil (RG), paddy highland (PH) and paddy lowland (PL)), rice type and gender. Each circle represents the observed fraction of fertilized plot given the number of farmed plots per plot property and rice type per game session. The size of the dot is proportional to the number of observations of the same values. The lines in colour are predictions from a logistic regression, while the grey ribbons represent the corresponding 95\% confidence intervals from the fixed effects. (b) Coefficients corresponding to trends (a) in the probability to apply fertilizers to a given plot property (rainfed with bad soil (RB), rainfed with good soil (RG), paddy highland (PH) and paddy lowland $(\mathrm{PL})$ ), rice type and gender. The regression coefficient estimates (dots) with their corresponding 95\% confidence intervals (whiskers) of the variables of the model used for prediction in (a). 


\section{References}

1. FAOSTAT. Lao People's Democratic Republic. 2019. Available online: http://www.fao.org/countryprofiles/index/ en/?iso3=LAO (accessed on 7 August 2020).

2. Castella, J.-C. Agrarian transition and farming system dynamics in the uplands of South-East Asia. In Conservation Agriculture and Sustainable Upland Livelihoods: Innovations for, With and by Farmers to Adapt to Local and Global Changes: Proceedings of the 3rd International Conference on Conservation Agriculture in Southeast Asia, Hanoi, Vietnam, 10-15 December 2012; CIRAD: Montpellier, France; NOMAFSI: Phu Ho Commune, Vietnam; University of Queensland: Brisbane, Australie, 2012; pp. 4-21. ISBN 978-2-87614-687-7.

3. Cook, S. Structural Change, Growth and Poverty Reduction in Asia: Pathways to Inclusive Development. Develop. Policy Rev. 2006, 6, s51-s80.

4. De Koninck, R. The Challenges of the Agrarian Transition in Southeast Asia. Labour Cap. Soc. 2004, 37, 285-288.

5. Humphrey, J. Prospects and Challenges for Growth and Poverty Reduction in Asia. Develop. Policy Rev. 2006, 24, s29-s49.

6. Nooteboom, G. Agrarian Change and the Governance of Poverty in Southeast Asia. In Proceedings of the 9th Euroseas Conference, Oxford, UK, 16-18 August 2017; University of Oxford: Oxford, UK, 2017.

7. Contzen, S.; Forney, J. Family farming and gendered division of labour on the move: A typology of farming-family configurations. Agric. Hum. Values 2017, 34, 27-40. [CrossRef]

8. Alexander, K.; Millar, J.; Lipscombe, N. Sustainable Development in the Uplands of Lao PDR. Sustain. Develop. 2010, 18, 62-70.

9. Alexander, K.; Case, P.; Jones, M.; Connell, J. Commercialising smallholder agricultural production in Lao People's Democratic Republic. Develop. Pract. 2017, 27, 965-980. [CrossRef]

10. Foppes, J. Knowledge Capitalization: Agriculture and Forestry Development at "Kum Ban" Village Cluster Level in Lao PDR; LEAP, NAFES: Vientiane, Laos, 2008.

11. FAO Laos at A Glance. Available online: http://www.fao.org/laos/fao-in-laos/laos-at-a-glance/en/ (accessed on 7 August 2020).

12. Alexander, K.S.; Greenhalgh, G.; Moglia, M.; Thephavanh, M.; Sinavong, P.; Larson, S.; Jovanovic, T.; Case, P. What is technology adoption? Exploring the agricultural research value chain for smallholder farmers in Lao PDR. Agric. Hum. Values 2020, 37, 17-32. [CrossRef]

13. Clarke, E.; Jackson, T.M.; Keoka, K.; Phimphachanvongsod, V.; Sengxua, P.; Simali, P.; Wade, L.J. Insights into adoption of farming practices through multiple lenses: An innovation systems approach. Develop. Pract. 2018, 28, 983-998. [CrossRef]

14. Moglia, M.; Alexander, K.S.; Thephavanh, M.; Thammavong, P.; Sodahak, V.; Khounsy, B.; Vorlasan, S.; Larson, S.; Connell, J.; Case, P. A Bayesian network model to explore practice change by smallholder rice farmers in Lao PDR. Agric. Syst. 2018, 164, 84-94. [CrossRef]

15. Philp, J.N.M.; Vance, W.; Bell, R.W.; Chhay, T.; Boyd, D.; Phimphachanhvongsod, V.; Denton, M.D. Forage options to sustainably intensify smallholder farming systems on tropical sandy soils. A review. Agron. Sustain. Develop. 2019, 39, 30.

16. FAO. Country Gender Assessment of Agriculture and the Rural Sector in Lao PDR; FAO Regional Office for Asia and the Pacific Food and Agriculture Organization of the United Nations: Vientiane, Laos, 2018.

17. Akter, S.; Rutsaert, P.; Luis, J.; Htwe, N.M.; San, S.S.; Raharjo, B.; Pustika, A. Women's empowerment and gender equity in agriculture: A different perspective from Southeast Asia. Food Policy 2017, 69, $270-279$.

18. Whitehead, A.; Kabeer, N. Living with Uncertainty: Gender, Livelihoods and Pro-Poor Growth in Rural Sub-Saharan Africa; Working Paper/Institute of Development Studies; IDS: Brighton, UK, 2001; ISBN 978-1-85864-366-3.

19. Kabeer, N. Gender Equality, Economic Growth, and Women's Agency: The "Endless Variety" and "Monotonous Similarity" of Patriarchal Constraints. Fem. Econ. 2016, 22, 295-321. [CrossRef]

20. Whitehead, A. The gendered impacts of liberalization policies of African agricultural economies and rural livelihoods. In The Gendered Impacts of Liberalization: Towards "Embedded Liberalism"? Routledge: London, UK, 2009; ISBN 0-203-88403-5.

21. Bryceson, D.F. Gender and generational patterns of African deagrarianization: Evolving labour and land allocation in smallholder peasant household farming, 1980-2015. World Develop. 2019, 113, 60-72. [CrossRef] 
22. SIDA. National Gender Profile of Agricultural Households, Lao PDR 2010. Report Based on The Lao Expenditure and Consumptrion Surveys, National Agricultural Census and the National Population Census; Food and Agriculture Organization of the United Nations: Vientiane, Laos, 2010.

23. Phouxay, K.; Tollefsen, A. Rural-Urban Migration, Economic Transition, and Status of Female Industrial Workers in Lao PDR. Popul. Space Place 2011, 17, 421-434.

24. Manivong, V.; Cramb, R.; Newby, J. Rice and Remittances: The Impact of Labour Migration on Rice Intensification. In Proceedings of the Southern Laos Australian Agricultural and Resource Economics Society Conference (56th), Fremantle, Australia, 7-10 February 2012.

25. Rigg, J. Moving lives: Migration and livelihoods in the Lao PDR. Popul. Space Place 2007, 13, 163-178.

26. Rigg, J. Unplanned Development: Tracking Change in South-East Asia; Zed Books: London, UK, 2012.

27. Alcon, F.; Tapsuwan, S.; Martínez-Paz, J.M.; Brouwer, R.; de Miguel, M.D. Forecasting deficit irrigation adoption using a mixed stakeholder assessment methodology. Technol. Forecast. Soc. Chang. 2014, 83, 183-193.

28. Feder, G.; Just, R.E.; Zilberman, D. Adoption of Agricultural Innovations in Developing Countries: A survey. Econ. Develop. Cult. Chang. 1985, 33, 255-298.

29. Hailu, B.K.; Abrha, B.K.; Weldegiorgis, K.A. Adoption and impact of agricultural technologies on farm income: Evidence from Southern Tigray, Northern Ethiopia. Int. J. Food Agric. Econ. 2014, 2, 91-106.

30. Knowler, D.; Bradshaw, B. Farmers' adoption of conservation agriculture: A review and synthesis of recent research. Food Policy 2007, 32, 25-48. [CrossRef]

31. Pannell, D.J.; Marshall, G.R.; Barr, N.; Curtis, A.; Vanclay, F.; Wilkinson, R. Understanding and promoting adoption of conservation practices by rural landholders. Aust. J. Exp. Agric. 2006, 46, 1407-1424.

32. World Bank. Agricultural Innovations Systems-An Investment Source Book; World Bank: Washington, DC, USA, 2012; p. 658.

33. Asian Development Bank. Lao PDR: Accelerating Structural Transformation for Inclusive Growth: Country Diagnostic Study; ADB: Manila, Philippines, 2017; ISBN 978-92-9257-994-4.

34. Villamor, G.B.; Badmos, B.K. Grazing game: A learning tool for adaptive management in response to climate variability in semiarid areas of Ghana. Ecol. Soc. 2016, 21, 39.

35. Garcia, C.A.; Savilaakso, S.; Verburg, R.W.; Gutierrez, V.; Wilson, S.J.; Krug, C.B.; Sassen, M.; Robinson, B.E.; Moersberger, H.; Naimi, B.; et al. The Global Forest Transition as a Human Affair. One Earth 2020, 2, 417-428. [CrossRef]

36. Vieira Pak, M.; Castillo Brieva, D. Designing and implementing a Role-Playing Game: A tool to explain factors, decision making and landscape transformation. Environ. Model. Softw. 2010, 25, 1322-1333. [CrossRef]

37. Barreteau, O.; Le Page, C.; D'aquino, P. Role-playing games, models and negotiation processes. J. Artif. Soc. Soc. Simul. 2003, 6, 1-10.

38. D'Aquino, P.; Le Page, C.; Bousquet, F.; Bah, A. Using self-designed role-playing games and a multi-agent system to empower a local decision-making process for land use management: The selfCormas experiment in Senegal. J. Artif. Soc. Soc. Simul. 2003, 6, 3.

39. Castella, J.-C.; Trung, T.N.; Boissau, S. Participatory simulation of land-use changes in the northern mountains of Vietnam: The combined use of an agent-based model, a roleplaying game, and a geographic information system. Ecol. Soc. 2005, 10, 27.

40. Perrotton, A.; de Garine-Wichatitsky, M.; Valls-Fox, H.; Le Page, C. My cattle and your park: Codesigning a role-playing game with rural communities to promote multistakeholder dialogue at the edge of protected areas. Ecol. Soc. 2017, 22, 35.

41. Basco-Carrera, L.; Meijers, E.; Sarısoy, H.D.; Şanli, N.O.; Coşkun, S.; Oliemans, W.; van Beek, E.; Karaaslan, Y.; Jonoski, A. An adapted companion modelling approach for enhancing multi-stakeholder cooperation in complex river basins. Int. J. Sustain. Develop. World Ecol. 2018, 25, 747-764. [CrossRef]

42. Redpath, S.M.; Keane, A.; Andrén, H.; Baynham-Herd, Z.; Bunnefeld, N.; Duthie, A.B.; Frank, J.; Garcia, C.A.; Månsson, J.; Nilsson, L.; et al. Games as Tools to Address Conservation Conflicts. Trends Ecol. Evol. 2018, 33, 415-426. [CrossRef]

43. Villamor, G.B.; van Noordwijk, M. Social Role-Play Games Vs Individual Perceptions of Conservation and PES Agreements for Maintaining Rubber Agroforests in Jambi (Sumatra), Indonesia. Ecol. Soc. 2011, 16, art27. [CrossRef] 
44. Ponta, N.; Cornioley, T.; Dray, A.; van Vliet, N.; Waeber, P.O.; Garcia, C.A. Hunting in Times of Change: Uncovering Indigenous Strategies in the Colombian Amazon Using a Role-Playing Game. Front. Ecol. Evol. 2019, 7, 1-19.

45. Garcia, C.; Dray, A.; Waeber, P. Learning Begins When the Game Is Over: Using Games to Embrace Complexity in Natural Resources Management. GAIA-Ecol. Perspect. Sci. Soc. 2016, 25, 289-291. [CrossRef]

46. Garcia, C.A.; Vendé, J.; Konerira, N.; Kalla, J.; Nay, M.; Dray, A.; Delay, M.; Waeber, P.O.; Stoudmann, N.; Bose, A.; et al. Coffee, Farmers, and Trees-Shifting Rights Accelerates Changing Landscapes. Forests 2020, 11, 480. [CrossRef]

47. Speelman, E.N.; García-Barrios, L.E.; Groot, J.C.J.; Tittonell, P. Gaming for smallholder participation in the design of more sustainable agricultural landscapes. Agric. Syst. 2014, 126, 62-75. [CrossRef]

48. Bos, S.P.M.; Cornioley, T.; Dray, A.; Waeber, P.O.; Garcia, C.A. Exploring livelihood strategies of shifting cultivation farmers in assam through games. Sustainability 2020, 12, 2438. [CrossRef]

49. Ouariachi, T.; Elving, W.J.L.; Pierie, F. Playing for a sustainable future: The case of We Energy Game as an educational practice. Sustainability 2018, 10, 3639. [CrossRef]

50. Villamor, G.B.; Dah-gbeto, P.A.; Bell, A.; Pradhan, U.; van Noordwijk, M. Gender-specific spatial perspectives and scenario building approaches for understanding gender equity and sustainability in climate-smart landscapes. In Climate-Smart Landscapes: Multifunctionality in Practice; World Agroforestry Centre (ICRAF): Nairobi, Kenya, 2015; pp. 211-224. ISBN 978-92-9059-375-1.

51. Sims Feldstein, H.; Jiggins, J. Tools for The Field: Methodologies Handbook for Gender Analysis in Agriculture; Feldstein, H.S., Jiggins, J., Eds.; Kumarian Press Library of Management for Development; Kumarian Press: West Hartford, CT, USA, 1994; ISBN 978-1-56549-028-4.

52. Villamor, G.B.; van Noordwijk, M.; Djanibekov, U.; Chiong-Javier, M.E.; Catacutan, D. Gender differences in land-use decisions: Shaping multifunctional landscapes? Curr. Opin. Environ. Sustain. 2014, 6, 128-133. [CrossRef]

53. Étienne, M. Companion Modelling: A Participatory Approach to Support Sustainable Development; Springer: Heidelberg, Germany, 2013; ISBN 978-94-017-8557-0.

54. Fisher, J.; Farré, I.; Dray, A.; Khimashia, N.; Perez, P. Serious games to explore uncertainty of future farms. In Proceedings of the 16th Australian Agronomy Conference, Armidale, New South Wales, Australia, 14-18 October 2012; Available online: http://www.regional.org.au/au/asa/2012/agriculture/8191_fisherjs.htm (accessed on 7 August 2020).

55. Alexander, K.; Larson, S.; Moglia, M.; Greenhalgh, G.; Case, P.; Perez, P.; Jovanovic, T.; Giger-Dray, A. Smallholder Farmer Decision-Making and Technology Adoption in Southern Lao PDR: A Synthesis of Findings; Report for ACIAR ASEM/2014/052 project 'Smallholder Farmer Decision-Making and Technology Adoption in Southern Laos: Opportunities and Constraints'; ACIAR: Canberra, ACT, Australia, 2017.

56. Alexander, K.; Larson, S. Smallholder Farmer Decision-Making and Technology Adoption in Southern Lao PDR: Opportunities and Constraints. Activity 1.5: Stakeholders Perceptions; Report for ACIAR ASEM/2014/052 Project 'Smallholder Farmer Decision-Making and Technology Adoption in Southern Laos: Opportunities and Constraints'; ACIAR: Canberra, Australia, 2016.

57. Alexander, K.; Parry, L.; Thammavong, P.; Sacklokham, S.; Pasouvang, S.; Connell, J.; Jovanovic, T.; Moglia, M.; Larson, S.; Case, P. Rice farming systems in Southern Lao PDR: Interpreting farmers' agricultural production decisions using Q methodology. Agric. Syst. 2018, 160, 1-10.

58. Larson, S.; Alexander, K. Smallholder Farmer Decision-Making and Technology Adoption in Southern Lao PDR: Opportunities and Constraints. Activity 1.4 Summary of the Secondary Livelihoods and Economic Data; Report for ACIAR ASEM/2014/052 project 'Smallholder Farmer Decision-Making and Technology Adoption in Southern Laos: Opportunities and Constraints'; ACIAR: Canberra, Australia, 2016.

59. Eliste, P.; Santos, N.; Pravongviengkham, P. Lao People's Democratic Republic Rice Policy Study; IRRI, WB: Rome, Italy, 2012.

60. Cramb, R.A.; Gray, G.D.; Gummert, M.; Haefele, S.M.; Lefroy, R.D.B.; Newby, J.C.; Stür, W.; Warr, P. Trajectories of Rice-Based Farming Systems in Mainland Southeast Asia; ACIAR Monograph No. 177; Australian Centre for International Agricultural Research (ACIAR): Canberra, Australia, 2015.

61. Stür, W.; Gray, G.D. Review of Rice-Based Farming Systems in Mainland Southeast Asia Working Paper 3. Livestock in Smallholder Farming Systems of Mainland Southeast Asia; University of Queensland Australia and International Centre for Tropical Agriculture (CIAT): Hanoi, Vietnam, 2014. 
62. Vote, C.; Newby, J.; Phouyyavong, K.; Inthavong, T.; Eberbach, P. Trends and perceptions of rural household groundwater use and the implications for smallholder agriculture in rain-fed Southern Laos. Int. J. Water Resour. Develop. 2015, 31, 558-574. [CrossRef]

63. World Bank (WB); International Rice Research Institute (IRRI). Lao People's Democratic Republic Rice Policy Study; Ministry of Agriculture and Forestry of the Lao People's Democratic Republic: Vientiane, Laos, 2012.

64. R Core Team. R: A Language and Environment for Statistical Computing; R Core Team: Vienna, Austria, 2019.

65. Bates, D.; Mächler, M.; Bolker, B.M.; Walker, S.C. Fitting linear mixed-effects models using lme4. J. Stat. Softw. 2015. [CrossRef]

66. Barr, D.J.; Levy, R.; Scheepers, C.; Tily, H.J. Random effects structure for confirmatory hypothesis testing: Keep it maximal. J. Mem. Lang. 2013, 68, 255-278. [CrossRef]

67. Chatman, J.A.; O’Reilly, C.A. Asymmetric Reactions to Work Group Sex Diversity Among Men and Women. AMJ 2004, 47, 193-208. [CrossRef]

68. Hernán-González, R.; Kujal, P. Gender differences in cooperation and competition. In Experimental Economics I: Economic Decisions; Palgrave Macmillan: London, UK, 2015; pp. 154-168.

69. Molina, J.A.; Giménez-Nadal, J.I.; Cuesta, J.A.; Gracia-Lazaro, C.; Moreno, Y.; Sanchez, A. Gender Differences in Cooperation: Experimental Evidence on High School Students. PLoS ONE 2013, 8, e83700. [CrossRef]

70. Charness, G.; Rustichini, A. Gender differences in cooperation with group membership. Games Econ. Behav. 2011, 72, 77-85. [CrossRef]

71. Balliet, D.; Li, N.P.; Macfarlan, S.J.; Van Vugt, M. Sex differences in cooperation: A meta-analytic review of social dilemmas. Psychol. Bull. 2011, 137, 881-909. [CrossRef]

72. Peshkovskaya, A.; Babkina, T.; Myagkov, M. Gender effects and cooperation in collective action: A laboratory experiment. Ration. Soc. 2019, 31, 337-353. [CrossRef]

73. Croson, R.; Gneezy, U. Gender Differences in Preferences. J. Econ. Lit. 2009, 47, 448-474. [CrossRef]

74. Moglia, M.; Alexander, K.S.; Larson, S.; (Giger)-Dray, A.; Greenhalgh, G.; Case, P. Gendered roles in agrarian transition: A study of lowland rice farming in Lao PDR. Sustainability 2020, 12, 5403.

75. Deere, C.D. The Feminization of Agriculture? Economic Restructuring in Rural Latin America; Occasional Paper; United Nations Research Institute for Social Development: Geneva, Switzerland, 2005; ISBN 978-92-9085-049-6.

76. Doss, C.R.; Morris, M.L. How does gender affect the adoption of agricultural innovations? The case of improved maize technology in Ghana. Agric. Econ. 2000, 25, 27-39. [CrossRef]

77. Ragasa, C. Improving Gender Responsiveness of Agricultural Extension. In Gender in Agriculture; Quisumbing, A.R., Meinzen-Dick, R., Raney, T.L., Croppenstedt, A., Behrman, J.A., Peterman, A., Eds.; Springer: Dordrecht, The Netherlands, 2014; pp. 411-430. ISBN 978-94-017-8615-7.

78. Peterman, A.; Behrman, J.A.; Quisumbing, A.R. A Review of Empirical Evidence on Gender Differences in Nonland Agricultural Inputs, Technology, and Services in Developing Countries. In Gender in Agriculture; Quisumbing, A.R., Meinzen-Dick, R., Raney, T.L., Croppenstedt, A., Behrman, J.A., Peterman, A., Eds.; Springer: Dordrecht, The Netherlands, 2014; pp. 145-186. ISBN 978-94-017-8615-7.

79. Bikketi, E.; Ifejika Speranza, C.; Bieri, S.; Haller, T.; Wiesmann, U. Gendered division of labour and feminisation of responsibilities in Kenya; implications for development interventions. Gender Place Cult. 2016, 23, 1432-1449. [CrossRef]

80. Fischer, E.; Qaim, M. Gender, agricultural commercialization, and collective action in Kenya. Food Secur. 2012, 4, 441-453. [CrossRef]

81. Ogunlana, E.A. The technology adoption behavior of women farmers: The case of alley farming in Nigeria. Renew. Agric. Food Syst. 2004, 19, 57-65. [CrossRef]

82. Doss, C.R. Designing Agricultural Technology for African Women Farmers: Lessons from 25 Years of Experience. World Develop. 2001, 29, 2075-2092. [CrossRef]

83. Castella, J.-C.; Bourgoin, J.; Lestrelin, G.; Bouahom, B. A model of the science-practice-policy interface in participatory land-use planning: Lessons from Laos. Landsc. Ecol. Pract. 2014, 29, 1095-1107.

(C) 2020 by the authors. Licensee MDPI, Basel, Switzerland. This article is an open access article distributed under the terms and conditions of the Creative Commons Attribution (CC BY) license (http://creativecommons.org/licenses/by/4.0/). 